\title{
Usage of Students' Potential in Biomedical and Health care Research in Bosnia and Herzegovina
}

\author{
Bosna Hersek'te Biyomedikal ve Sağlık Hizmetleri Araştırmalarında \\ Ögrenci Potansiyelinin Kullanılması
}

\author{
Emir BEGAGIC $\bullet$, Nermin DUZIC $\bullet$, Zlatan MEMIC $\bullet$, Nemanja ARANDELOVIC $\bullet$ \\ Anida CELEBIC $\odot$, Hakija BECULIC $\odot$
}

Ethics Committee Approval: This study was approved by rectory of European University of KallosTuzla, 18 December 2020,01-1334-2/20.

Conflict of interest: The authors declare that they have no conflict of interest.

Funding: None.

Informed Consent: Informed consent was taken from the participants of the study.
Cite as: Begagic E, Duzic N, Memic Z, Arandelovic N, Celebic A, Beculic H. Usage of students' potential in biomedical and health care research in Bosnia and Herzegovina. Medeni Med J. 2021;36:44-51.

\begin{abstract}
Objective: To provide relevant insight into the current degree of usage of the research potential of students of biomedical sciences in Bosnia and Herzegovina.

Method: The chosen data collection method was online surveying via Google search engine. The target group were students of biomedical sciences in Bosnia and Herzegovina. The surveying was conducted in July 2019, and responses were subjected to descriptive statistics.

Results: Although the majority of participants claimed that they were familiar with the seminar and scientific papers writing methodology and that the related course is available in their faculty's curriculum, the quality of such courses may be questioned as the majority of study participants selfreported that they do not possess or did not posses necessary knowledge for writing and publishing a scientific paper. Also, the majority of respondents reported that they have never participated in any scientific research, which questions the involvement of students in scientific research in our country as well. More than half of respondents were actively reading scientific papers, but a third of them did not have that habit. Two-thirds of students reported that they have never attended any scientific event where they could learn more about the scientific research methods. Inadequate awareness of the importance of research, lack of students' interest in making a research, and lack of knowledge were characterized as main obstacles in conducting scientific research according to survey responses.

Conclusion: Information obtained through research indicate that the student potential in scientific research in Bosnia and Herzegovina has not been used in its maximal capacity, requiring several steps to be taken towards its improvement.
\end{abstract}

Keywords: biomedical, research, students, Bosnia and Herzegovina

öz

Amaç: Bosna Hersek'teki biyomedikal bilimler öğrencilerinin araştırma potansiyelinin mevcut kullanım derecesine ilişkin uygun içgörü sağlamak.

Yöntem: Google form aracilığıyla çevrimiçi anket çalışması ile veriler toplanmıştır. Araştırma grubu Bosna Hersek'teki biyomedikal bilimler öğrencileridir. Anket, Temmuz 2019'da uygulanarak yanıtlar betimleyici istatistiksel analizlere tabi tutulmuştur.

Bulgular: Araştırmaya katılanların çoğu, seminer ve bilimsel makale yazma metodolojisine aşina olduklarını ve ilgili dersin kendi fakültelerinin müfredatında mevcut olduğunu iddia etseler de bunların çoğunluğu bilimsel bir makale yazmak ve yayınlamak için gerekli bilgi birikiminde bir eksiklik olduğunu belirttiği için, bu tür derslerin kalitesi sorgulanabilir. Ayrıca, ankete katılanların önemli bir bölümü, öğrencilerin ülkede bilimsel araştırmalara dahil olmasını sorgulayan hiçbir bilimsel araştırmaya katılmadıklarını belirtmislerdir. Ankete katılanların yarısından fazlası, aktif olarak bilimsel makale okuduğunu bildirmiştir ancak üçte birinin bu alışkanlığının olmadığı görülmüsstür. Öğrencilerin üçte ikisi, bilimsel araştırma yöntemleri hakkında daha fazla bilgi edinebilecekleri hiçbir bilimsel etkinliğe katılmadıklarını bildirmiștir. Anket yanıtlarına göre, araștırma yürütmenin önemi konusunda zayıf düzeyde farkındalık, öğrencilerin araştırma hakkında ilgi ve bilgi eksikliği, bilimsel araştırma yürütmenin önündeki başlıca engeller olarak nitelendirilebilir.

Sonuc: Araștırmada elde edilen bulgular, Bosna Hersek'teki bilimsel araștırmalardaki öğrenci potansiyelinin en üst kapasitede kullanılmadığını ve bu durumun iyileştirilmesi için birçok adım atılması gerektirdiğini göstermektedir.

Anahtar kelimeler: Biyomedikal, araştırma, öğrenciler, Bosna Hersek
Received: 28 November 2020

Accepted: 26 January 2021

Online First: 26 March 2021

Corresponding Author: E. Begagic

ORCID: 0000-0002-3988-8911

University of Zenica, Medical Faculty,

Zenica, Bosnia and Herzegovina

begagicem@gmail.com

Z. Memic

ORCID: 0000-0002-0799-5501

A. Celebic

ORCID: 0000-0003-4431-2375

University of Zenica, Medical Faculty,

Zenica, Bosnia and Herzegovina

N. Duzic

ORCID: 0000-0003-1091-1978 Inernational Burch University,

Department of Genetics and Bioengineering,

Sarajevo, Bosnia and Herzegovina

H. Beculic

ORCID: 0000-0002-6904-2490 Cantonal Hospital Zenica,

Department of Neurosurgery,

Zenica, Bosnia and Herzegovina

N. Arandelovic

ORCID: 0000-0002-4672-1407

European University Kallos,

Medical Faculty,

Tuzla, Bosnia and Herzegovina 


\section{INTRODUCTION}

Biomedical sciences encompass a wide group of natural sciences applied to technology, knowledge and interventions that are used in healthcare or public health. These include but are not limited to: medical microbiology, clinical virology, biomedical engineeering, genetics, pharmacy etc. ${ }^{1}$.

Research in the field of biomedical science in Bosnia and Herzegovina is in a phase of stagnation. One of the factors that contribute to this situation is the unused students' potentials in terms of scientific research. The main goal of this paper is to define and help understand these factors and present their influence on the research. Based on the results, it would also be possible to draw certain conclusions and suggest possible steps that should be taken, to improve the current situation and increase the scientific research activity of students in Bosnia and Herzegovina and their awareness regarding its importance.

The problem of unused students' potentials in scientific research is not only a problem in Bosnia and Herzegovina but also in the world. For instance, two-thirds of medical students in the UK graduate without experience in scientific research ${ }^{2,3}$. Otherwise, examples of good practice are medical schools in Germany, where about $66 \%$ of medical students publish papers in Medline-indexed publications ${ }^{4}$.

There are numerous benefits and advantages of participating in scientific research. According to a study by Dutch researchers, students who had published their scientific research before graduation: (i) were almost two times more likely to continue publishing papers, (ii) published more articles, and (iii) had a higher citation impact after they graduated $^{5}$.

The research aims to provide relevant insight into the current state regarding student's research within the field of biomedical sciences in Bosnia and Herzegovina. Also, the students' awareness regarding the importance of scientific research and the most common obstacles in pursuing their research are investigated.

\section{MATERIAL and METHODS}

The methodology of our research was the online survey conducted using Google search engine. Students of biomedical sciences from either public or private universities in Federation of Bosnia and Herzegovina and Republic of Srpska and Brčko District in Bosnia and Herzegovina. The survey was conducted online from $10^{\text {th }}$ to $16^{\text {th }}$ July 2019 and contained 22 questions. Survey participants were asked to indicate what did they study, at which study cycle, and which faculty they were enrolled in. They were asked to estimate the availability of scientific research in our country, to self-evaluate their knowledge and experience in scientific research, and to indicate the main obstacles in pursuing scientific research in our country. The results of the survey were processed in the Microsoft Excel.

\section{RESULTS}

In this study, a survey was created to examine the usage of students' potential in biomedical researches in Bosnia and Herzegovina. The survey was intended for students of biomedical sciences studying at either public or private universities in Bosnia and Herzegovina. The survey was conducted online through Google Forms and a total of 418 participants responded.

When asked to indicate at which faculty they were studying, the majority of them $(n=207)$ answered that they were studying at Faculty of Medicine, the Faculty of Health Sciences $(n=80)$, Pharmacy $(n=68)$, Faculty of Natural Sciences and Mathematics $(n=30)$, Dentistry $(n=6)$ and 27 participants answered that they were studying something else (Table 1). 
Table 1. Distribution of students according to the faculty at which they study.

\begin{tabular}{lr}
\hline Faculty & $\begin{array}{c}\text { Number of } \\
\text { participants }\end{array}$ \\
\hline Faculty of Medicine & 207 \\
Faculty of Health Sciences & 80 \\
Pharmacy & 68 \\
Faculty of Dental Medicine & 6 \\
Faculty of Natural Sciences and Mathematics & 30 \\
Faculty of Veterinary Medicine & 0 \\
Other & 27 \\
\end{tabular}

Table 2 below represents a number of students studying a particular subject of interest.

Table 2. Number of students studying the particular subject of interest.

\begin{tabular}{lr}
\hline Subject of interest & $\begin{array}{c}\text { Number of } \\
\text { participants }\end{array}$ \\
\hline General Medicine & 155 \\
Nursing & 85 \\
Pharmacy & 70 \\
Radiology & 17 \\
Stomatology/dental medicine & 16 \\
Genetic engineering & 13 \\
Biochemistry & 11 \\
Sanitary engineering & 11 \\
Physical therapy & 6 \\
Biology & 4 \\
Other & 30 \\
\end{tabular}

Table 3 indicates at which study cycle and year of study participants were enrolled at the moment of surveying. Out of the total number of participants, 374 answered that they were studying at the first cycle, 34 for a master's degree and 10 participants were studying at a doctoral degree or equivalent.

Table 3. Distribution of students according to the respective study cycle and year of study.

\begin{tabular}{lcr}
\hline Cycle & Year of Study & $\begin{array}{c}\text { Number of } \\
\text { participants }\end{array}$ \\
\hline & 1 & 63 \\
First (Bachelor) & 2 & 95 \\
& 3 & 129 \\
& 4 & 55 \\
Second (Master) & 5 & 23 \\
Third (Doctoral Study) & 6 & 9 \\
& 1 & 21 \\
& 2 & 13 \\
& 1 & 4 \\
& 2 & 4 \\
\hline
\end{tabular}

Table 4 summarizes the number of students enrolled at each study cycle. The majority of students were attending the first or Bachelor cycle.

Table 4. Distribution of participants according to study cycle.

\begin{tabular}{lc}
\hline Cyle of the study & Numerically (n) / percentage (\%) \\
\hline I cylce - Bachleor & 377 / 90 \\
II cycle - Master & 33 / 8 \\
III cycle - Doctoral study & $8 / 2$
\end{tabular}

Participants were further asked to indicate if they got familiar with the methodology of writing seminar papers through studies. A total of 367 participants answered positively and 51 negatively (Table 5 - A). Table 5 - B shows that courses regarding scientific research methods are mainly available at faculties in Bosnia and Herzegovina. When asked to self-report if they acquired the necessary knowledge to write and publish a scientific paper, 152 participants answered positively and 266 negatively (Table 5 - C).

Table 5. A: Number of participants that are familiar/unfamiliar with seminar paper writing methodology; B: Availability of courses treating scientific research methods; C: Percentage of students who have/have not acquired knowledge for scientific research according to selfevaluation.

\begin{tabular}{lll}
\hline & \multicolumn{2}{c}{$\begin{array}{c}\text { Answers / Results } \\
\text { [numerically (n) / } \\
\text { percentage (\%)] }\end{array}$} \\
\cline { 2 - 3 } Question/subject & Yes & No \\
\hline A $\begin{array}{l}\text { Famialitary with writing a scientific } \\
\text { paper }\end{array}$ & $367 / 88$ & $51 / 12$ \\
B $\begin{array}{l}\text { Availability of course that treats } \\
\text { scientific research methods }\end{array}$ & $301 / 72$ & $117 / 28$ \\
C $\begin{array}{l}\text { Number/percentage of students } \\
\text { that have/have not acquired } \\
\text { enough knowledge to conduct } \\
\text { scientific research }\end{array}$ & $152 / 36 \quad 266 / 64$ \\
\end{tabular}

Subsequently, participants were asked to tell if they participated in any scientific research work. A total of 118 participants answered positively and 300 negatively (Table 6). 
E. Megagic et al., Usage of students' potential in biomedical and health care research in Bosnia and Herzegovina

Table 6. Number of students participating in scientific research.

\begin{tabular}{ll}
\hline Paticipation in research & Numerically (n) / percentage (\%) \\
\hline Yes & $118 / 28$ \\
No & $300 / 72$ \\
\hline
\end{tabular}

Table 7 below depicts whether participants have authored or co-authored any scientific research paper.

Table 7. Number of students that authored or co-authored any research paper.

\begin{tabular}{lll}
\hline & Yes (n / \%) & No (n / \%) \\
\hline Author & $60 / 14$ & $358 / 86$ \\
Coauthor & $65 / 16$ & $353 / 84$ \\
\hline
\end{tabular}

Participants were then asked to evaluate the incentive of professors and lecturers in higher education institutions and the involvement of students in scientific researches. A total of 101 participants answered that incentive and involvement were insufficient, 142 marked them as strong, 108 considered them as weak, 48 as very good, and 21 said that they were both excellent (Figure 1).

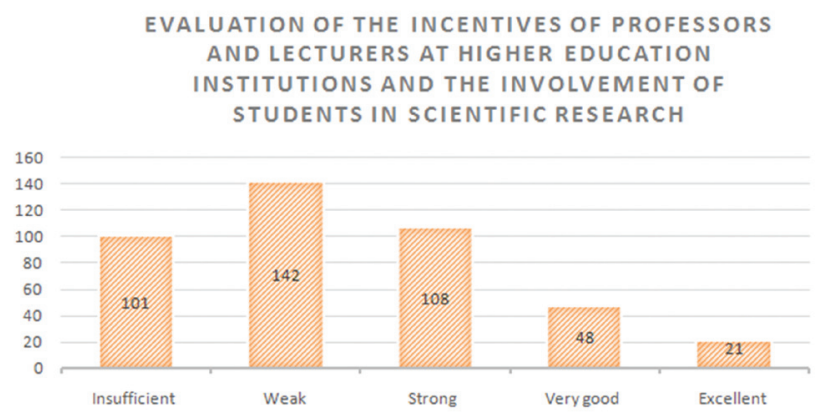

Figure 1. Evaluation of professors' incentive and students' involvement in scientific research.

Participants were asked to indicate if they were actively reading scientific research studies published in national or international journals in the field of biomedicine and health. A total of 260 participants answered positively and 158 negatively (Table 8 - A). According to survey results, 328 students used published research papers as sources when preparing their seminar papers (Table 8 - B). Additionally, participants were asked if they had ever attended any conference, roundtable, or seminar where they could learn about the methodology of writing, editing, and publishing a research paper. A total of 139 participants answered positively and 278 negatively (Table 8 - C).

Table 8. A: Number of participants who actively read scientific research papers within the field of biomedicine and health; B: Number of participants using published research for purposes of preparing their seminar papers; C: Number of participants who attended scientific events that could help them improve their writing, editing, and publishing skills.

\begin{tabular}{|c|c|c|c|}
\hline & \multirow[b]{2}{*}{ Question/subject } & \multicolumn{2}{|c|}{$\begin{array}{l}\text { Answers / Results } \\
\text { [numerically (n) / } \\
\text { percentage (\%)] }\end{array}$} \\
\hline & & Yes & No \\
\hline $\mathbf{A}$ & $\begin{array}{l}\text { Number/percentage of students } \\
\text { actively reading scientific research } \\
\text { published in national or international } \\
\text { journals }\end{array}$ & $158 / 38$ & $260 / 62$ \\
\hline B & $\begin{array}{l}\text { Number/percentage of students } \\
\text { using scientific research papaers as } \\
\text { sources when writing seminar } \\
\text { papers }\end{array}$ & $328 / 78$ & $90 / 22$ \\
\hline C & $\begin{array}{l}\text { Number/percentage of students } \\
\text { who have attended conferences, } \\
\text { roundtables, or seminars where they } \\
\text { learned about the methodology of } \\
\text { writing, editing and publishing a } \\
\text { research paper }\end{array}$ & $139 / 33$ & 279 / 67 \\
\hline
\end{tabular}

Participants were asked to indicate and report the greatest obstacle for students in writing a scientific paper in Bosnia and Herzegovina (Table 9)

Table 9. Main obstacles in conducting scientific research in BiH.

\begin{tabular}{lc}
\hline $\begin{array}{l}\text { Main obstacles in conducting } \\
\text { scientific research in BiH }\end{array}$ & $\begin{array}{l}\text { Numerically (n) / } \\
\text { percentage (\%) }\end{array}$ \\
\hline $\begin{array}{l}\text { Students are not interested } \\
\text { Students are not introduced to }\end{array}$ & $164 / 39$ \\
$\begin{array}{l}\text { methodology } \\
\text { Weak awarness about importance of } \\
\text { research } \\
\begin{array}{l}\text { Other } \\
\hline\end{array}\end{array}$ & $140 / 34$ \\
& $11 / 3$
\end{tabular}


Furthermore, students were asked to evaluate the usage of potentials for purposes of writing scientific research and the majority of them (166) considered it as insufficient (Figure 2).
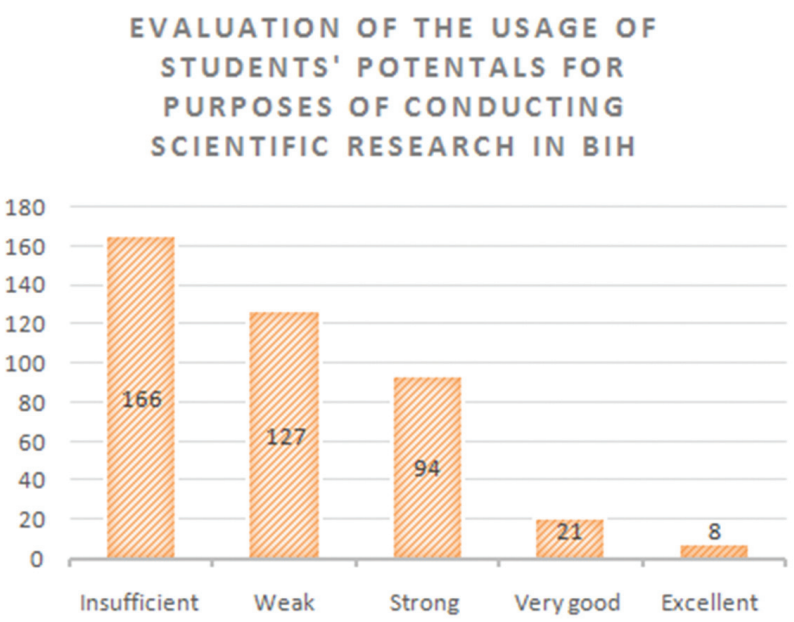

Figure 2. Evaluation of usage of students' potential in conducting scientific research in BiH.

Finally, students were asked if they would like to participate in scientific research. A total of 401 participants answered positively and 17 negatively (Table 10).

Table 10. A number of students who would like to participate in scientific research (\%).

\begin{tabular}{lc}
\hline $\begin{array}{l}\text { Number and percentage of students } \\
\text { who would like to participate in } \\
\text { scientific research }\end{array}$ & $\begin{array}{l}\text { Numerically (n) / } \\
\text { percentage (\%) }\end{array}$ \\
\hline Yes & $401 / 96$ \\
No & $17 / 4$ \\
\hline
\end{tabular}

\section{DISCUSSION}

Medical school graduates in Germany cannot achieve the title of MD until they submit a thesis of their research. As a result of such a rule, a huge majority of practicing physicians in Germany undertake a certain research program ${ }^{6}$. This type of research activity is usually not mandatory in the UK, however, there is an increment in the interest of undergraduate students for research and publication, which is even stimulated by spe- cial reward programs that award credits to medical graduates for their first paper published in a peer-reviewed journal ${ }^{7}$. Studies suggest that undertaking research training may help future doctors to be able to evaluate clinical evidence critically and leverage their research skills to gain greater and deeper understanding which would have a positive influence on their practice ${ }^{7-10}$. However, the fact is that medical students in the UK have a limited opportunity to work on their original research. Instead, institutions are offering intercalated degree courses, where students have a choice to suspend their medical training if they want to undertake a second degree instead, which often comes along with a strong research component ${ }^{2,3,7}$. However, the fact is that twothirds of UK students have not undertaken such a degree and may graduate without research experience. The most commonly cited barriers to intercalate were financial constraints, lack of interest, and reluctance to prolong medical training $^{7}$. Academic supervisors at one German institution came out with the information that students appeared as co-authors on approximately $28 \%$ of papers published in Medline-indexed journals, while works of about two-thirds (66\%) of medical students in Germany are published in Medline - indexed journals before obtaining their degree of $\mathrm{MD}^{4,7}$.

Although research activity can influence both personal development and medical education in a positive way, the fact is that it is not an obliged part of syllabuses and important component of medical education in developing countries and the fact is that both the interest and involvement of students in medical research and obstacles they face in accessing it have not been appropriately addressed ${ }^{11,12}$. In their study conducted in Brazil, the authors aimed to evaluate the degree of availability of scientific research training in medical schools as well as the involvement of medical students in these researches. Additionally, the authors tried to identify possible barriers to students' involvement and the lack of such scien- 
tific research programs and activities. They examined 13 medical programs in six Brazilian states and interviewed 1004 medical students in total. The survey examined the distribution of scientific activities in the institutions at which students were enrolled, the students' willingness to participate in such activities, and reasons for not participating.The results of their survey revealed that only $7 \%$ of medical students have not expressed any interest in research studies. However, $60 \%$ of them were involved in research training. Lack of institutional motivation, defective infrastructure, and unavailability of university professors for mentoring were the most commonly mentioned barriers. Although the survey revealed that 8 of 13 schools have investigated the scientific programs, an average of $47 \%$ of the students participated in these programs. This study identified that, alhtough scientific training during medical education was inadequate, the majority of students were, however, interested in research activities ${ }^{11,12}$.

Peeva and colleagues aimed to examine the preparedness of medical students for scientific work. For those purposes, they surveyed 278 Bulgarian and English medical students attending the second and fourth years of study. Data processing was subjected to predictive analytics software IBM SPSS Statistics. The results of the survey showed that almost all students had a certain level of experience with scientific research. The majority of them gained it through presentations and essays, while $94 \%$ of them used scientific literature. Despite all, $76 \%$ of survey respondents claimed that they had a lack of knowledge and would rather undertake a scientific research program $^{13}$.

To the best of the authors' knowledge, this study is the first to the date to examine the usage of students' potential in biomedical and nursery research in Bosnia and Herzegovina. After the research was successfully conducted, the conclusion was made that the majority of students in
Bosnia and Herzegovina are interested in scientific research. The majority of participants stated that they were familiar with the methodology of writing seminar papers and that the course that treats scientific work and its methodology was available in their faculty's curriculum. On another side, the quality of such courses may be the subject of question or discussion, as the majority of study participants self-reported a lack of necessary knowledge for writing and publishing a scientific paper. Also, the majority of respondents reported that they had never participated in any scientific research, which questions the involvement of students in scientific research in our country. A total of 142 and 101 students evaluated the incentives of professors and lecturers at their faculties and involvement of students in scientific research as weak and insufficient respectively. More than half of respondents were actively reading scientific papers, but more than a third of them had not this habit. Two-thirds of students reported they have never attended any scientific event where they could learn more about the scientific research methods. The main obstacles in conducting scientific research in Bosnia and Herzegovina defined by this study are as follows: (i) weak awareness of the importance of research (ii) students' insufficient interest in scientific research, (iii) students inappropriately introduced into the methodology of scientific research. Finally, the majority of participants responded that they would like to participate in scientific research, but they found usage of students' potential in conducting scientific research in Bosnia and Herzegovina was rather insufficient.

However, the results of this study may be a subject of bias as the majority of students came from the faculty of medicine (155/418) and health sciences (85/418). Additionally, out of 418 participants, 374 were enrolled in the first study cycle, which may be also a reason for having biased results, which in turn can be considered as a limitation of this study. 
There are numerous benefits of students' participation in the creation of a scientific work, and they are well-documented for graduates, institutions, and academic communities. A study conducted on medical students in neighboring Croatia showed that participation in research activities was directly correlated with a significantly more positive attitude towards science ${ }^{14}$. Therefore, in order to secure a future of biomedical sciences and academic medicine, senior doctors and professors shall consider involving more students in extracurricular research projects, as well as to recognize the importance of student research and incorporate such opportunities into the curriculum when available.

\section{CONCLUSION}

The main objective of this study was to provide insight into the current level of utilization of students' potential in terms of conducting scientific research within the field of biomedical sciences.

According to the data obtained from the research, we can draw several conclusions as follows: (i) The majority of students in Bosnia and Herzegovina believe that the potential of students in scientific research is not sufficiently used in our country. (ii) Although the methodology of scientific research is studied through curricular courses at the faculties with the biomedical orientation in Bosnia and Herzegovina, students consider them as not of sufficient quality and not providing them with a level of knowledge that would give them enough self-confidence to handle a scientific work. (iii) According to survey results, professors at universities in Bosnia and Herzegovina are not making enough effort to bring students closer to the benefits of participating in scientific research, as students are not given enough opportunities to participate in scientific research. (iv) Although a large percentage of students actively read up-todate scientific literature, the majority of them have never participated in any scientific research, which indicates that the student potential in
Bosnia and Herzegovina has not been used in its full capacity.

To improve the current state of utilization of students' potential in scientific research, the following steps may be taken:(i) The syllabus of scientific research courses needs to be re-evaluated and improved with a focus on the work methodology and practical experience in research, (ii) Professors and lecturers should create and find more opportunities for involving their students in scientific research, (iii)Students should be more strongly encouraged to participate at scientific congresses and to undertake a scientific research.

\section{REFERENCES}

1. UK Health Departments. The Future of the Healthcare Science Workforce: Modernising Scientific Careers: The Next Steps. United Kingdom; 2009. Available from: https://www.ahcs.ac.uk/wordpress/wp-content/ uploads/2013/09/MSC-Consultation-the-future-of-theHCS-Workfoce-dh_091533.pdf

2. Greenhalgh T, Wong G. Doing an intercalated BSc can make you a better doctor. Med Educ. 2003;37:760-1. [CrossRef]

3. Agha R, Howell S. Intercalated BSc degrees - why do students do them? Clin Teach. 2005;2:72-6. [CrossRef]

4. Cursiefen $\mathrm{C}$, Altunbas A. Contribution of medical student research to the Medline-indexed publications of a German medical faculty. Med Educ. 1998;32:439-40. [CrossRef]

5. Waaijer CJF, Ommering BWC, van der Wurff LJ, van Leeuwen TN, Dekker FW; NVMO Special Interest Group on Scientific Education. Scientific activity by medical students: the relationship between academic publishing during medical school and publication careers after graduation. Perspect Med Educ. 2019;8:223-9. [CrossRef]

6. Diez C, Arkenau C, Meyer-Wentrup F. The German medical dissertation--time to change? Acad Med. 2000;75:861-3. [CrossRef]

7. Metcalfe D. Involving medical students in research. J R Soc Med. 2008;101:102-3. [CrossRef]

8. Jacobs $C D$, Cross PC. The value of medical student research: the experience at Stanford University School of Medicine. Med Educ. 1995;29:342-6. [CrossRef]

9. Field S. Tomorrow's doctors. BMJ. 2009;339:b2696. [CrossRef]

10. Houlden RL, Raja JB, Collier CP, Clark AF, Waugh JM. Medical students' perceptions of an undergraduate research elective. Med Teach. 2004;26:659-61. [CrossRef]

11. de Oliveira NA, Luz MR, Saraiva RM, Alves LA. Student views of research training programmes in medical 
E. Megagic et al., Usage of students' potential in biomedical and health care research in Bosnia and Herzegovina

schools. Med Educ. 2011;45:748-55. [CrossRef]

12. Zaidi S, Nasir M. Additional teaching subjects. In: Teaching and Learning Methods in Medicine. Springer, Cham; 2015. p. 151-237. [CrossRef]

13. Peeva K, Tsokeva J, Dyakova V. Medical students' atti- tude to creating scientific work. Knowledge International Journal. 2018;28:717-21. [CrossRef]

14. Mileder LP. Medical students and research: Is there a current discrepancy between education and demands? GMS Z Med Ausbild. 2014;31:15. [CrossRef] 